\title{
Web Based Information System in Coffee Cirengot 33 Bandung
}

\author{
Endang Amalia \\ Widyatama University, Information System, Bandung, \\ 40125, Indonesia \\ endang.amalia@widyatama.ac.id
}

\author{
Rendi* \\ Widyatama University, Information System, Bandung, \\ 40125, Indonesia \\ rendi@widyatama.ac.id \\ *Corresponding author
}

\begin{abstract}
This study aims to help solve the problem Reservation of cirengot coffee shop places is still done manually and transaction reports are still manual on 33 cirengot roads in the city of Bandung where the study was conducted. The background of writing this report is because there are several problems that exist around ordering food and beverages are still manual and transaction reports are still manual. Research data collection through the process of library study and interview process. The research method used is the research action design and the development method is Prototype. While modeling the system using Unified Modelling Language is expected that all three can maximize the desired results. Research conducted includes the creation of a website-based coffee shop information system covering several factors, namely the data management system starting from the owner, employee, financial statements, income, expenses and also there is the preparation of financial reports. It is hoped that the development of web-based information systems can overcome the problems that exist in the Bandung Cirengot coffee shop.
\end{abstract}

Keywords-Information Systems, e-ecommerce, Prototype, Website-based Applications, Action Design Research, unified model language.

\section{INTRODUCTION}

Information technology is developing very fast. The impact of the development of information technology offers the community the opportunity to meet all their needs. The demands of the public, who desire comfort for each of their activities and needs, present a problem for entrepreneurs and businessmen to provide their consumers with the best possible service and to provide adequate opportunities to meet their needs. Many services from the Internet can be used in various business areas. In this last project the information system for internet cafe's is being developed.

The cafe is well known to Indonesians today. Many Indonesians prefer to enjoy coffee in the café. Enjoying coffee in a café has become a lifestyle for Indonesia today. A café is a place where drinks such as coffee, tea and other drinks are offered. There are also several cafes that offer snacks as a supplement.

This system is intended for the development of information media in Café Cirengot Jl. Cirengot No. 33 Bandung, namely information media in the form of pamphlets, brochures, leaflets and catalogs. Because of the availability of services over the Internet, visitors can find out about Cirengot coffee shop profiles, products, and online orders.

\section{LITERATURE REVIEW}

Recorded in 2017 the number of coffee shops in the region The Special Region of Yogyakarta has reached 1,200 coffee shops but with so many coffee shops in the Yogyakarta area, coffee connoisseurs find it difficult to buy coffee beans as they wish. and also many coffee companies who want to use website applications (Darmawan, 2009) In an industry, it must be willing to continue to grow and achieve success, which is the main vision to be achieved, with the development of the business world today accompanied by the emergence of competitors, making a company or industry must continue to innovate to be able to improve information and promotion of products and locations, one of from companies that want to innovate is Authentic Coffee (Robiyan, 2017) The demands of the public who want convenience in each of their activities and needs, is a challenge for business people to provide maximum service to their consumers by providing adequate facilities to meet their needs. Many facilities from the digital world can be utilized in various business fields, one of which is a Web application (Luthfi, 2017). While modeling the system using Unified Modelling Language is expected that all three can maximize the desired results (Nugroho, 2010)

\section{RESEARCH METHODS}

The authors use the Action Design Research method that is to explain a social situation at the same time by making changes or interventions with the aim of improvement or participation (Pressman, 2010). 
The following is an explanation of each work cycle referred to in Picture 1:

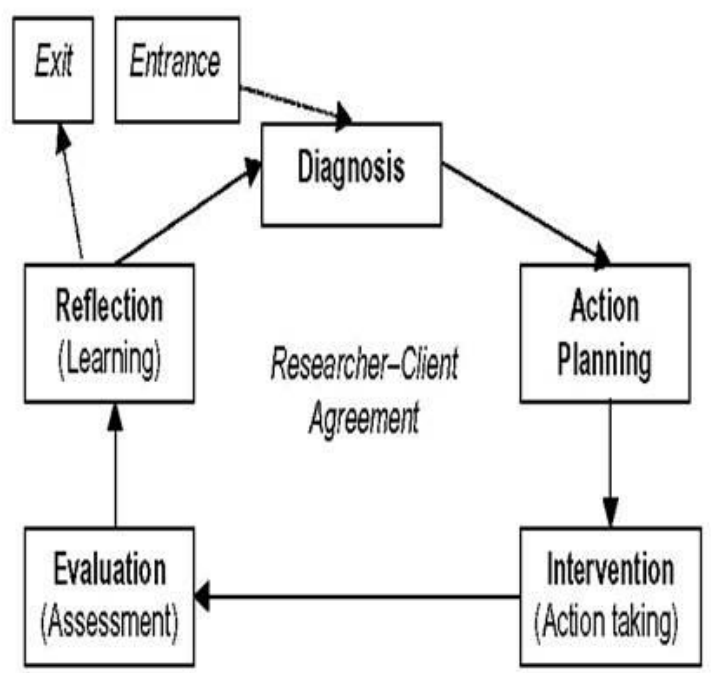

Picture 1. Action Design Research

a. Diagnosing

In this study researchers conducted data collection in 3 ways namely:

A. Literature review

B. Interview

C. Observation

b. Action Planning

Why the authors use this method because this method is often used and has advantages seen from the systematic and detailed stages of system development. There are four stages of the research process using prototypes, namely the requirements analysis and definition stage, the user interface prototyping stage, the architecture \& component design prototyping stage, and the implementation and system testing stage. The following is an explanation of each stage of the research conducted (Pressman, 2010):

1. Stage Requirement Analysis And Definition

At this stage an analysis of the problem exists that is happening to the object of research. Analysis of the problem was carried out with a literature study, an interview with the store staff at coffee cirengot Bandung. In addition to analyzing the problem, a needs analysis is also done, this needs analysis will later be used as a tool used in the process of making a prototype to become a finished application.

2. Stage of User Interface Prototyping

After the system needs analysis has been carried out, the next step is to re-identify the system requirements. If the system requirements have been identified properly, the next process can be carried out, namely the creation of a prototype user interface. This prototype user interface is the appearance and interaction of the application being built.
3. Architecture \& Component Design Prototyping After the prototype user interface has been completed, the next process is to design and prototype architecture and application components that are built and later used as a reference to create the final application.

4. Implementation and System Testing Stage

Furthermore, if all the previous processes have been carried out, then a prototype is produced which is used as a reference in making the application. After the application is completed, the application testing or testing process is carried out for the examiner or knowing the quality of the application that has been built.

c. Action taking

Researchers and participants jointly implement an action plan in the hope of resolving the problem. Furthermore, after the model is based on a sketch and adjusts the content to be displayed based on the needs of stakeholders. Furthermore, it is carried out by conducting initial trials offline and then continuing to rent space on the internet with the aim that the website can be displayed online.

d. Assessment

in this stage, it is seen how the user's acceptance of the website is marked by various activities.

e. Learning

At this stage it is the final part of all the cycles that have been passed by carrying out a review of the phases that have ended then this research can end.

\section{RESULTS AND DISCUSSION}

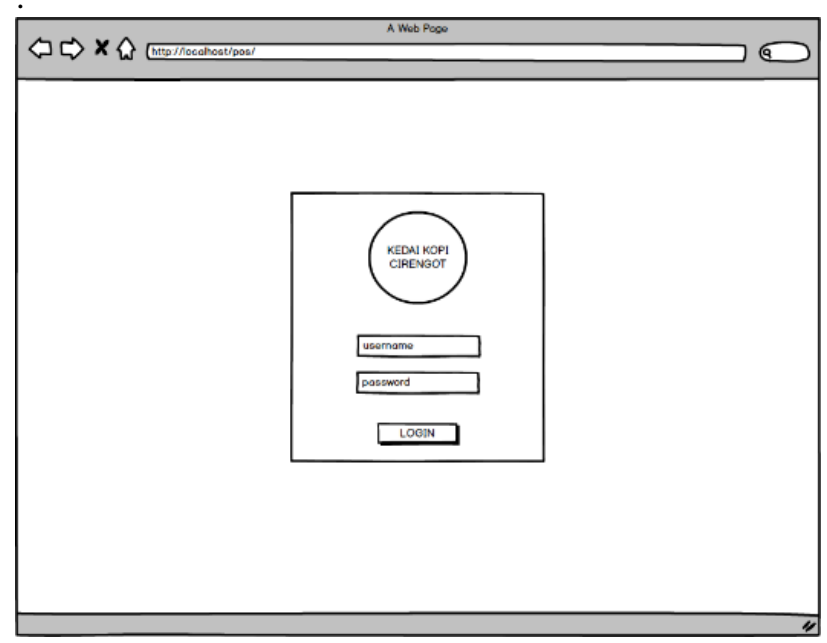

Picture 2. Login Mockup

Login form appears from the main page to give access rights to the user, by entering a username and password then select access rights.

This report form has two submenus, namely a transaction report that contains details of previous sales transactions, then for financial reports, namely the total 
coffee shop revenue during the sale or can be filter using monthly or annual features in it:

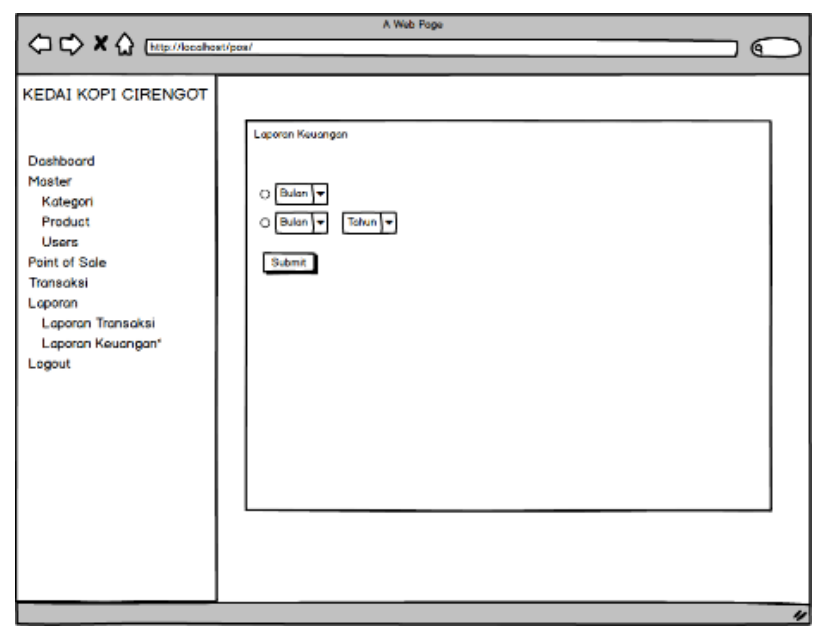

Picture 3. Report Interface Mock-up

Software Requirement:

For supporting software that will be used to run this application is:

1. Windows 7 Operating System or above.

2. Virtual webserver uses XAMPP.

3. PHP 5.

4. MySQL.

5. Browser applications like Google Chrome or Mozilla Firefox.

From the results of research and development of this academic information system, the authors can draw conclusions that:

1. The information system built can be accessed by internal parties (owners and cashiers).

2. The system built can display food and drinks online.

3. The system built can display and produce data on transaction reports and overall transaction report data

Tabel 1. Blackbox System Testing

\begin{tabular}{|c|l|c|c|}
\hline No & \multicolumn{1}{|c|}{ Testing Items } & Sub Items & Result \\
\hline 1 & Login & Input validation & Success \\
\hline 2 & Owner & Input validation & Success \\
\hline & & Suitability of the process & Success \\
\hline 3 & Employee & Input validation & Success \\
\hline 4 & Finance & Suitability of the process & Success \\
\hline & & Suitability of the process & Success \\
\hline 5 & Income & Input validation & Success \\
\hline 6 & Spending & Suitability of the process & Success \\
\hline
\end{tabular}

\begin{tabular}{|c|l|c|c|}
\hline & & Suitability of the process & Success \\
\hline 7 & Report & Input validation & Success \\
\hline & & Suitability of the process & Success \\
\hline
\end{tabular}

\section{CONCLUSION}

Based on the description that has been stated in the previous chapters, then in this last chapter contains the conclusions raised by the author and also suggestions that are useful for further development. The information system built can be accessed by internal parties (owners and cashiers). The system built can display food and drinks online. The system built can display and produce data on transaction reports and overall transaction report data

\section{REFERENCES}

Darmawan, Adhi. 2017. "Sistem Informasi Coffee Shop Pada Kedai Kopi Kupas Berbasis Web Menggunakan Php Dan Mysql," Sistem Informasi Coffee Shop Pada Kedai Kopi Kupas Berbasis Web Menggunakan Php Dan Mysql.

Luthfi, Akhmad. 2017. "Sistem Informasi Penjualan Berbasis Web Pada Kedai Kopi Abg," Sistem Informasi Penjualan Berbasis Web Pada Kedai Kopi Abg.

Nugroho, Andi. 2010. Rekayasa Perangkat Lunak Berbasis Objek Dengan Metode Usdp, Jogjakarta: Andi, 2010.

Robiyan, Rahmanda. 2017. "Perancangan Sistem Informasi Cafe Otentik Kopi Berbasis Web," Perancangan Sistem Informasi Cafe Otentik Kopi Berbasis Web.

S. Pressman, Roger. 2010 Rekayasa Perangkat Lunak, Yogyakarta: Andi, 2010. 